\title{
The U.S. and Irish credit crises: Their distinctive differences and common features ${ }^{\text {is }}$
}

\author{
Gregory Connor $^{\mathrm{a}, *}$, Thomas Flavin ${ }^{\mathrm{a}}$, Brian O'Kelly ${ }^{\mathrm{b}}$ \\ a NUI Maynooth, Ireland \\ ${ }^{\mathrm{b}}$ Dublin City University, Ireland
}

Keywords:

Credit crises

Asset price bubbles

Capital bonanzas

Regulatory imprudence

Moral hazard

\begin{abstract}
A B S T R A C T
Although the 2007-2008 US credit crisis precipitated it, the subsequent Irish credit crisis is an identifiably separate one, which might have occurred in the absence of the U.S. crash. The distinctive differences between them are notable. Many of the apparent causal factors of the U.S. crisis are missing in the Irish case; and the same applies vice versa. At a deeper level, we identify four common features of the two credit crises: capital bonanzas, asset price bubbles, regulatory imprudence, and moral hazard. The particular manifestations of these four "deep" common features are quite different in the two cases.
\end{abstract}

() 2011 Elsevier Ltd. All rights reserved.

\section{Introduction}

This paper compares two linked, but separate, credit crises in the U.S. and Ireland, explores the differences between them, and reaches some tentative conclusions about the "deep" common features which caused them. The two crises are interesting theoretically since, although they occurred nearsimultaneously in two closely linked economies, from a superficial perspective they are quite different. The two main building blocks for explaining the 2007-2008 U.S. crisis, subprime mortgages and mortgage-related securities, were almost entirely absent from the Irish capital market and from Irish financial institutions' balance sheets. Three of the four catalysts for the subsequent Irish crisis were absent from the U.S. case: large net borrowing by the banking sector in foreign debt markets, extremely overpriced property markets relative to fundamentals, and very unsafe lending by the banking sector for speculative property development. A fourth catalyst was the knock-on effects of the

\footnotetext{
Wh wish to acknowledge support from the Science Foundation of Ireland under grant 08/SRC/FM1389.

* Corresponding author.

E-mail addresses: gregory.connor@nuim.ie (G. Connor), thomas.flavin@nuim.ie (T. Flavin), brian.okelly@dcu.ie (B. O’Kelly).
} 
U.S. liquidity-credit crisis, particularly its effect on the interbank borrowing market. The Irish credit environment was so precarious at the time of the U.S. crash that it is arguable that the Irish credit crisis would have occurred even in the absence of this fourth catalyst.

We explore the differences between the two crises, and argue for four common features which served as "deep" causal factors in the two crises. The first of these common features is the presence of asset price bubbles. In both countries asset price bubbles developed during unusually benign economic climates, the Great Moderation period in the USA and the Celtic Tiger period in Ireland. The second common feature is very low real borrowing rates sustained by international capital inflows into both countries (but inflows of different types of capital). Reinhart and Reinhart (2008) call this a capital bonanza and we follow their terminology. The third is regulatory imprudence in response to political pressure by special interests (but different types of political pressures serving different special interests in the two countries). The fourth is moral hazard behaviour by agents in the financial sector and (for Ireland) in the property development industry. The particular mechanisms by which these common features caused credit crises in the two countries are surprisingly different in the two cases.

As noted by Cabellero and Krishnamurthy (2008), a distinguishing feature of financial crises is that they are all superficially different, at least from the most recently preceding ones, since economic agents are well-prepared for any set of circumstances clearly similar to those in recent past crises. This lack of obvious historical repetition makes social scientific analysis more subtle, since this type of analysis relies on historical sample data to build models that explain and forecast. Explaining a particular financial crisis on a superficial level will have little relevance for forecasting or preventing future ones. Hence it is important to work at a deeper level in the search for common features. Our case-study comparison of these two crises involves too small a sample to reach definitive conclusions, but we believe it is illuminating and worthwhile. At a minimum, comparison of these two crises may persuade researchers not to draw excessively general conclusions from superficial examination of the particular circumstances of the U.S. crisis alone. Another credit crisis occurred nearly simultaneously to the more prominent U.S. one, in an economy closely linked to the US economy, and yet the specific causal mechanisms for the crisis were very different. Given this, general conclusions from the particularities of the U.S. crisis are problematic.

In a series of papers and a book, Reinhart and Rogoff (2008a,b, 2009) provide a comprehensive overview of financial crises across many countries and covering several centuries of financial history. Our paper is informed by the Reinhart and Rogoff research programme, and we use some of their taxonomy, but we compare these two crises with a finer level of granularity than their much broader coverage of global economic and financial history. Two of the four common features that we identify, capital bonanzas and asset price bubbles, appear prominently in the Reinhart and Rogoff analysis. The other two, regulatory imprudence and moral hazard, reflect the managerial, mixed-economy nature of both the US and Irish economies. In both cases, governmental and managerial errors played a key role in causing the crises, which would not be possible in the broad historical sample considered by Reinhart and Rogoff.

Section 2 compares the U.S. credit-liquidity crisis and the subsequent Irish banking crisis highlighting the substantial, somewhat surprising, differences between them. Section 3 discusses the asset price bubbles which seem evident with hindsight in both the US and Irish economies in the periods leading up to their crises. Section 4 describes the strong international capital inflows into both countries during the pre-crisis periods, and the artificially low real interest rates that these capital inflows supported. Section 5 looks at regulatory imprudence in the US and Ireland in the periods leading up to the crises, and how this imprudence developed in response to domestic political pressures. Section 6 looks at moral hazard behaviour by economic agents in the two countries, and discusses how this contributed to each crisis. Section 7 summarizes and concludes the paper.

\section{Differences between the US and Irish crises}

We begin by reviewing some key events in each of the two crises. ${ }^{1}$ The US crisis was the first to emerge. The slowdown in real estate prices and the consequent downturn experienced after 2006 led

1 Brunnermeier (2009) provides a more comprehensive review of the US crisis. 
to uncertainty in the value of mortgage pass-throughs and related securities. Investors became increasingly concerned about the valuation of these pooled and tranched products. As most risk models used inputs that were estimated during a period of appreciating property prices and favourable economic conditions, they under-estimated the true risk of the securitized assets in the face of a common shock. Coval et al. (2009) argue that a neglected feature of the securitization process is that it substitutes risks that are largely diversifiable for risks that are highly systematic.

Downward pressure in asset values and credit quality led to a decrease in tranche prices. Consequently, the rating agencies were forced to downgrade many of the mortgage-backed securities, often by several notches. For example, Craig et al. (2008) report that 90\% of the CDO tranches underwritten by Merrill Lynch were downgraded from AAA-rated to 'junk'. These downgrades compounded the problems in the market as institutional investors with ratings-based mandates were compelled to sell off these assets in extremely thin markets. This further compounded the downward spiral in tranche prices.

Dwyer and Tkac (2009) estimate that global equity and government bond markets are approximately 100 times larger than the subprime mortgage-backed asset market. Despite the relatively small size of this market, such was the toxicity of its assets and the lack of transparency and information surrounding them that the turmoil was quickly and powerfully transmitted across many markets and countries. Brunnermeier and Pedersen (2009) model how adverse shocks in one market can spread throughout the financial system. In the case of the US crisis, three key markets were affected. One, the mortgage passthrough market, two, the credit derivatives market and in particular credit derivatives related to underlying mortgage assets, and three, related financing markets including the repo market. Many of the mortgage securities were purchased by conduits, structured investment vehicles, and other types of funds. These funds financed their purchases by issuing asset-backed commercial paper. This financing method meant there was a high degree of leverage underpinning the mortgage securities markets.

The negative sentiment towards subprime mortgage assets spilled over into markets for other structured debt. Liquidity shortages were exacerbated by a lack of appetite on the part of investors for commercial paper even if backed by assets other than mortgages. This followed a run on money market funds because investor sought to hold only very short-term assets. This caused the transmission of the crisis from institutions that were directly exposed to the US subprime market to those that relied on short-term financing to fund their operations. Many funds were forced to call on the contingent liquidity lines provided by their bank sponsor. This put further pressure on bank liquidity. As the bad news continued to flow, concern grew about the solvency of some market participants. Counterparty credit concerns caused banks to hoard liquid assets. Market liquidity evaporated and prices for all but the most liquid securities dipped. Libor rose substantially as banks were unwilling to lend to one another.

The US crisis emerged from a mis-understanding of the liquidity and credit risks associated with an abundance of complex, relatively new financial products. The US crisis also precipitated a global liquidity crisis.

While the emergence of the US crisis was evident from mid-2007 as mortgage defaults began to gather pace, the Irish crisis did not manifest itself until a year later. In common with many countries (see Aït-Sahalia et al., 2009) Ireland did not feel the full force of the turmoil until the collapse of Lehman Brothers sent shock waves through international financial markets. The drying up of liquidity exposed the fragility of the Irish financial sector. This vulnerability arose from a banking sector that had become hugely over-exposed on the asset side to the domestic property and construction sector, and on the liability side to interbank Euro borrowing markets; see Kelly (2009).

The global liquidity crisis following the Lehman Brothers collapse had severe repercussions for Irish financial institutions, who found it difficult to roll over their enormous foreign borrowings. Their problems were compounded by the rapidly deteriorating credit quality of their loan books, due to adverse conditions in the domestic property market. Falling housing and office demand and lower sales prices combined to increase the default rate of property developers on loans. Irish financial institutions came to the brink of extinction as many of their loans became impaired and significant write-downs became unavoidable.

The full extent of the crisis in Ireland was brought into sharp focus in late September 2008 when, only days after the Irish financial regulator had publicly assured investors as to the solidity of Irish banks, the Irish government chose to step in and guarantee the deposits and debts of the six largest financial institutions. The guarantee covered all retail and corporate deposits, interbank deposits, 
covered bonds, senior unsecured debt and dated subordinated debt. Although only one bank (reputedly Anglo Irish Bank) was clearly unable to refinance its short-term liabilities at that date, the government feared a systemic contagion if one bank was forced into liquidation. The government took drastic action to stop such a scenario.

It is not clear that Anglo Irish Bank represented a systemic risk. Anglo Irish had a limited retail presence; it operated by making large-scale commercial loans funded by institutional borrowing. Other banks may have wanted Anglo Irish included in the government support schemes since, as was subsequently revealed, many developer loans with different banks were secured with the same collateral, creating a complex web that would be difficult and costly to unwind if Anglo Irish alone were allowed to fail.

While the government bailout of Irish banks on September 30, 2008 was ostensibly to provide confidence to the system and allow Irish banks to continue to borrow on international capital markets, it has had much more far-reaching consequences for the Irish economy. The bailout created a contingent claim on the Irish state of approximately $€ 400$ billion - more than double Irish GDP. Irish sovereign debt yields and credit default swap (CDS) spreads jumped in the aftermath of the bailout announcement, e.g. the Irish-German 5-year CDS spread almost doubled on the day of the bailout, from 241 to 469 bps. Furthermore, the blanket guarantee created political tensions for Ireland as many of her European neighbours were unhappy with Ireland's unilateral action. Aït-Sahalia et al. (2009) report that such liability guarantee programmes tend to send mixed signals to market participants and raise fears about the health of the international financial system.

As well as the blanket guarantee, the government also promised to recapitalize the banks if and when it was deemed necessary. Initially, the major banks expressed confidence that this financial assistance would not be required. Speaking at the Oireachtas ${ }^{2}$ Committee on Finance and the Public Service, Donal Forde, managing director of Allied Irish Bank, said: "We are not all the same. Allied Irish Bank has made it clear we don't feel we need capital". However, this optimism was proved to be misplaced. In the aftermath of the bailout, the true extent of the banking problems began to slowly emerge and resulted in continued pressure on the Irish sovereign credit quality. In January 2009, Anglo Irish Bank was nationalised as the Government determined that a recapitalisation programme could not save this institution, while in February the two foremost banks, Bank of Ireland and Allied Irish Bank, received capital injections of $€ 3.5$ billion each.

As bad news continued to flow from the Irish banking sector, the Irish sovereign came under increasing scrutiny. On March 30, 2009, Irish sovereign debt lost its much-coveted AAA rating when S\&P downgraded it to $\mathrm{AA}+$. The other main rating agencies followed suit and this began a series of debt downgrades that saw Irish debt yields and market-implied probability of default rise throughout early 2009.

As the Irish banking crisis unfolded, it became increasingly clear that indigenous Irish banks were unable to operate as normal and in particular, extend credit to businesses. In an attempt to restore confidence to Irish banks and clean up their balance sheets, the Irish Government launched the National Asset Management Agency (NAMA). The remit of this institution was to buy the riskiest loans of the Irish banks at a price that reflected their long-term economic value, thus promoting investor confidence in the banks and helping them to resume their normal functions. In return, the banks were paid with government guaranteed securities, which could be used as collateral for European Central Bank (ECB) liquid funding. In essence, NAMA can take a longer-term view of working out these loans and has a 7-10 year time horizon. It is envisaged that NAMA will acquire a loan portfolio of approximately $€ 80$ billion. Following a loan-by-loan analysis, the transfer of eligible loans to NAMA began in May 2010 and the level of impairment became obvious. The average discounts applied to the acquired loans were almost 50\% for the first, over 55\% for the second and a predicted $58 \%$ for the third and final tranche of eligible loans.

Another destabilizing factor for the Irish economy during this period was the increasing gap between government income and expenditure. An over-reliance on property-related taxes meant that the collapse of the housing market had a devastating impact on tax revenues. Ireland's financial difficulties continued to mount as the Irish banking system required further capital injections. The budget situation

2 Oireachtas is the Irish term for parliament. 
was worsened by a Eurostat ruling that money pumped into Anglo Irish Bank did not represent an investment and thus should be treated as government spending. Consequently the 2009 deficit was revised upwards to approximately 14.5\% of GDP and the 2010 deficit reached 32\% of GDP. As of March 2011, Irish banks have received approximately $€ 50$ billion in recapitalisation funds from the state.

Problems in Greece brought other countries in the Eurozone with similar problems into sharp focus. The Irish government found itself unable to borrow, while deposits steadily drained from the domestic banks. Ireland was forced into a position where it had to accept a bailout package from the EU and IMF in November of 2010. Under the terms of the bailout, Ireland will receive funding of up to $€ 67.5$ billion in return for an IMF- and EU-monitored programme of fiscal retrenchment and economic reform. Furthermore, Ireland has promised to repay all (sovereign and bank) bondholders in full.

An obvious big difference between the US and Irish crises is the troubled assets behind them. The US 2007-08 credit-liquidity crisis followed a period of rapid financial innovation, during which many complex new products were introduced. The true aggregate risk profile of several technically complex, interlinked US financial markets was not properly understood by regulators and participants, precipitating a credit-liquidity crisis. In contrast, the Irish crisis evolved from a traditional credit boom and bust. Irish domestic financial institutions availed of cheap short-term funds using Eurodenominated bonds and interbank borrowing from Euro-area banks. The Irish banks used these funds to extend excessive credit to domestic property developers. Irish banks' loan books were also poorly diversified, with an over-concentration on speculative development loans in an over-heated Irish property market, while their liabilities included a large proportion of "hot money" interbank deposits. These features made the Irish banks extremely vulnerable to the global liquidity crisis.

Irish domestic banks were not involved in financial securitization to any great extent. At the time of the crisis, Irish banks had not yet adopted the 'originate-and-distribute' model for mortgage financing which was dominant in the US. Irish banks still overwhelmingly employed the more traditional 'originate-and-hold' model. Approximately $75 \%$ of all bank loans were held on-balance sheet and consequently the credit risk remained with the originating bank. Unlike in Germany and Japan, Irish financial institutions also did not have any significant exposure to US-based mortgages or other USbased securitized assets in their investment portfolios.

A related difference between the two crises was that the subprime mortgage market was in its infancy in Ireland when the US crisis hits. Although mortgage quality had declined in Ireland during the latter part of the Irish credit boom, the credit quality of most new mortgages was still relatively high by contemporary US standards.

\section{Asset price bubbles}

As Reinhart and Rogoff (2009) make clear, the causal factors behind financial crises typically lie in the boom periods preceding them. Asset price bubbles often develop during such booms, resulting in a sustained deviation between asset prices and fundamentals that cannot be explained by random shocks. Asset price bubbles are associated with periods of aggregate over-confidence and overoptimism in security markets, often attracting new traders and speculators to the market. Their presence, leading to over-inflated asset prices and excessive aggregate risk-taking, seems a clear common feature of the both the US and Irish crises.

US financial markets were relatively tranquil during the early years of this century. Also, the speed with which they recovered from adverse shocks, such as the collapse of the dot.com bubble, may have served to imbue a feeling of invincibility among some market participants. Furthermore, the bailout to the US financial system in the wake of the LTCM collapse (see Lowenstein, 2000) served to reinforce the belief that certain participants were 'too big to fail' and would receive government support if trouble flared. US financial institutions proceeded to pursue riskier strategies in the search for higher yield and from 2002 to 2007 they were largely successful. Financial services industry common stocks enjoyed large returns in both the US and Ireland.

Fig. 1 presents the cumulative increase in the market-wide equity indices in the US and Ireland from 1995 to 2010. Clearly, stock markets in both countries enjoyed a sustained period of success up to 2007. However, these gains were not uniformly distributed across all sectors, with the financial sector in both countries out-performing the rest of the domestic market. This is captured in Fig. 2, which shows the 


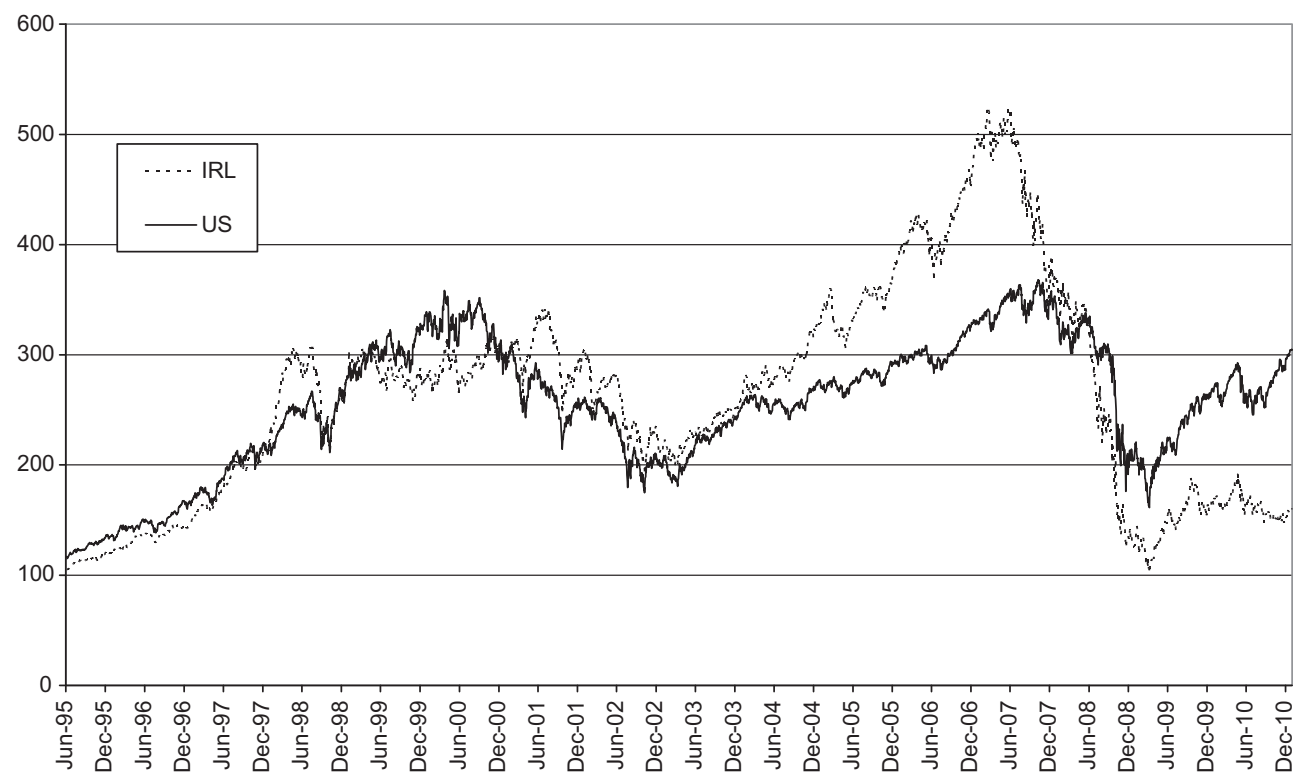

Fig. 1. US and Irish total stock market price indices.

relative performance of the financial sector to the total domestic market for both the US and Ireland. In both countries, financial stock prices grew rapidly relative to the total market index until the crisis began to unfold. The Irish financial sector increased in value about twice that of other domestic stocks, compared to about 1.5 times in the USA.

In Ireland, the rising confidence was generated by a sustained period of economic growth, leading Ireland to be internationally acclaimed as the 'Celtic Tiger'. Over the period 1994-2006, the Irish economy grew rapidly with an average annual growth rate of approximately $7 \%$ and unemployment falling to around $4 \%$ (near full employment). The economic boom and the subsequent 'feel-good factor' generated widespread over-confidence and contributed to the development of price bubbles in the financial and property markets. This was the explanation offered to angry shareholders by Allied Irish Bank chairman, Dermot Gleeson, in May 2009:

"We drank too deeply from the national cup of, I suppose, confidence ... The national mood of selfconfidence brewed itself up into overdrive."

The pre-crisis period was a sustained period of real estate price appreciation in both Ireland and the US. In Ireland, residential and commercial property experienced huge price increases. A report by the International Monetary Fund (2008) found that Ireland had the largest deviation of house prices from fundamentals among a sample of 21 developed OECD countries at the end of the pre-crisis period (December 2007). Fig. 3 shows average residential house prices from 1990 to 2010. Irish house prices experienced rapid appreciation from the mid-1990s onwards. Between May 1996 and May 2000, average Irish house prices doubled. One can make a convincing case that this late-1990s house price doubling in Ireland was not a property bubble, rather, it represented a rational revaluation of Ireland's housing stock. ${ }^{3}$

\footnotetext{
${ }^{3}$ For example, Kelly (2009) differentiates between the real-efficiency-based Irish growth phase of the late-1990s and the Irish property and construction bubble of the early 2000s. Although he does not provide an explicit turning point, Kelly makes a convincing case that the second, subsequent doubling of house prices in Ireland (from 2000 to 2006) was a credit-fuelled price bubble.
} 


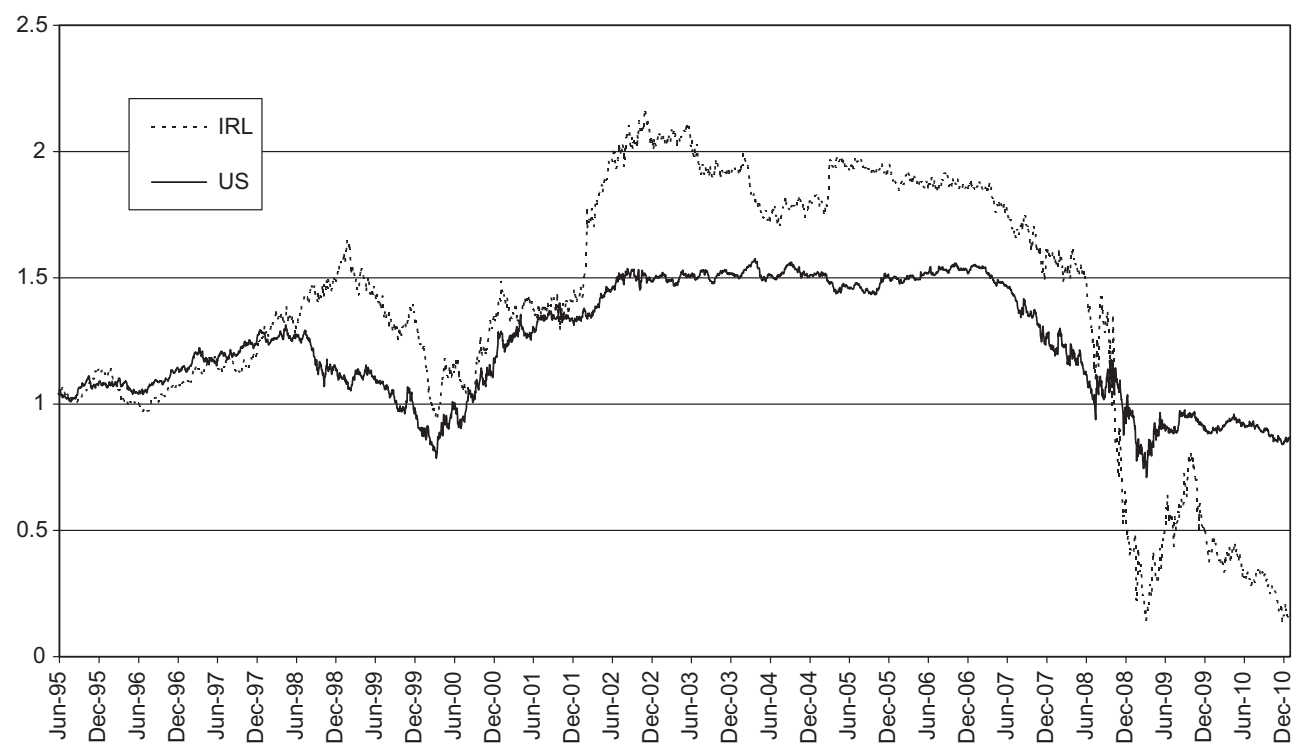

Fig. 2. Performance of the US and Irish financial services sector indices relative to their national market equity indices.

For the US, many commentators have noted (e.g., Gorton, 2008) that the subprime mortgage market was fundamentally built on the assumption of ongoing house price increases. A typical subprime mortgage was structured to refinance after a two- or three-year period. Such refinancing was only possible if the house price had increased. In this way, a self-fulfilling bubble was generated as excessive

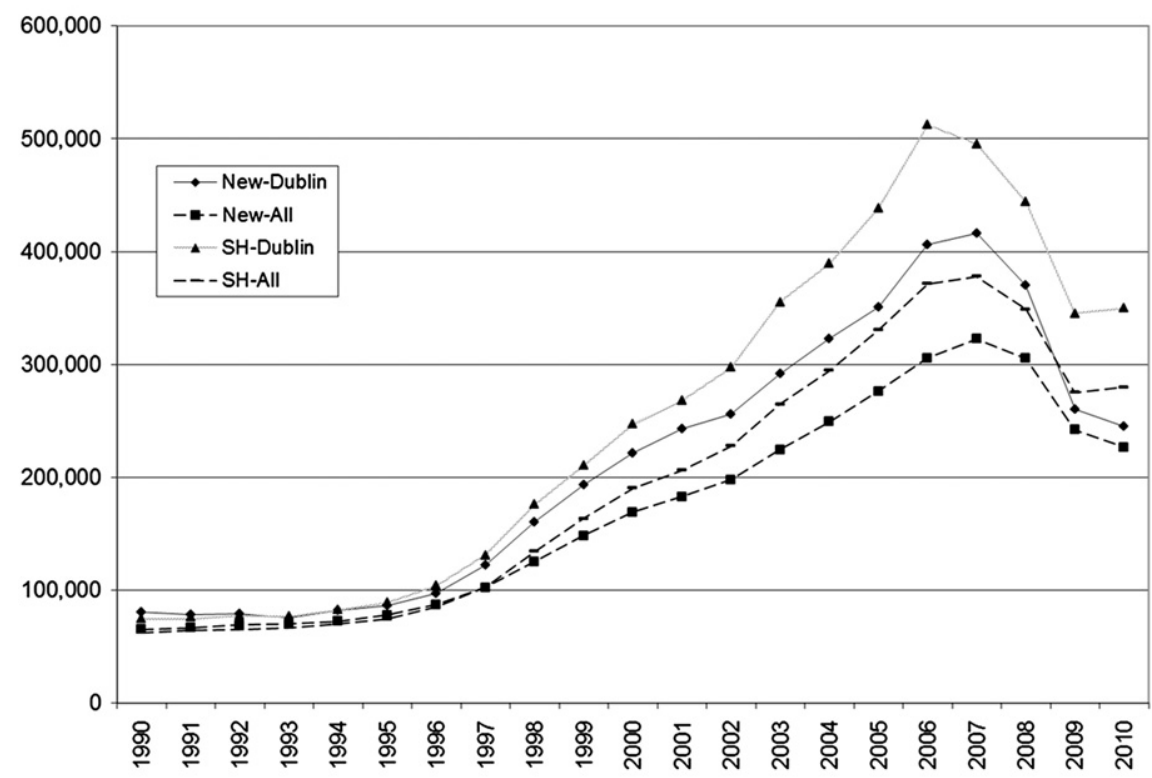

Fig. 3. Irish new and second-hand house prices - 1990-2010. 
mortgage lending fed upon itself; with the growth of mortgage lending increasing housing prices and justifying the assumption of further house price growth.

Fig. 4 compares house prices indices for Ireland with two alternative measures for the US from 2000 to 2010. The US indices are the Case-Shiller and the Federal Housing Finance Agency (FHFA). The former is based on house prices from twenty metropolitan areas and thus excludes rural areas; while the latter covers the entire country but omits higher value houses. Fig. 4 confirms that Irish house price appreciation was rapid and at least on a par with the US experience which also had strong house price appreciation during the 2000-2005 period. The implosion of the Irish bubble began later than in the US but the decline has been more severe and as of December 2010 has shown little tendency to bottom out.

The Irish housing boom began as a rational response to increasing demand. Ireland experienced net inward migration, and there also was a desire by the indigenous population to upgrade the existing housing stock in response to increasing per-capita income levels. During the early part of the Celtic Tiger period, increases in supply (see Fig. 5) were unable to match this demand and hence prices began to increase sharply. This price trend was exacerbated during the later years from 2000 to 2006 when over-aggressive bank lending flooded the market with property developers and speculative investors; see Kelly (2009). Another key feature of an asset price bubble, as noted by Kindleberger (1989), is that traders are often not interested in the asset for its intended use or its earning capacity but only in its expected price appreciation. In Ireland, this was reflected in a significant increase in the number of vacant properties, especially in the investment sector of the market (see FitzGerald, 2005). As prices soared, Kelly (2007) and Rae and van den Noord (2006) both warned of the need for government and regulators to take corrective action in Irish property markets, with Kelly (2007) predicting house price declines of $60 \%$ over $8-9$ years.

It has been argued that an overzealous imposition of restrictions on house planning and land rezoning contributed to the rising price of real estate in certain areas of the US; see Sowell (2010). Even though the Irish house price boom occurred alongside a strong growth in the supply of dwellings, planning regulations and restrictions also played a role in the development of the bubble. Regulations made it difficult to construct new rural dwellings; instead there was a drive to build housing estates within existing towns and villages. These restrictions served to increase the value of the stock of

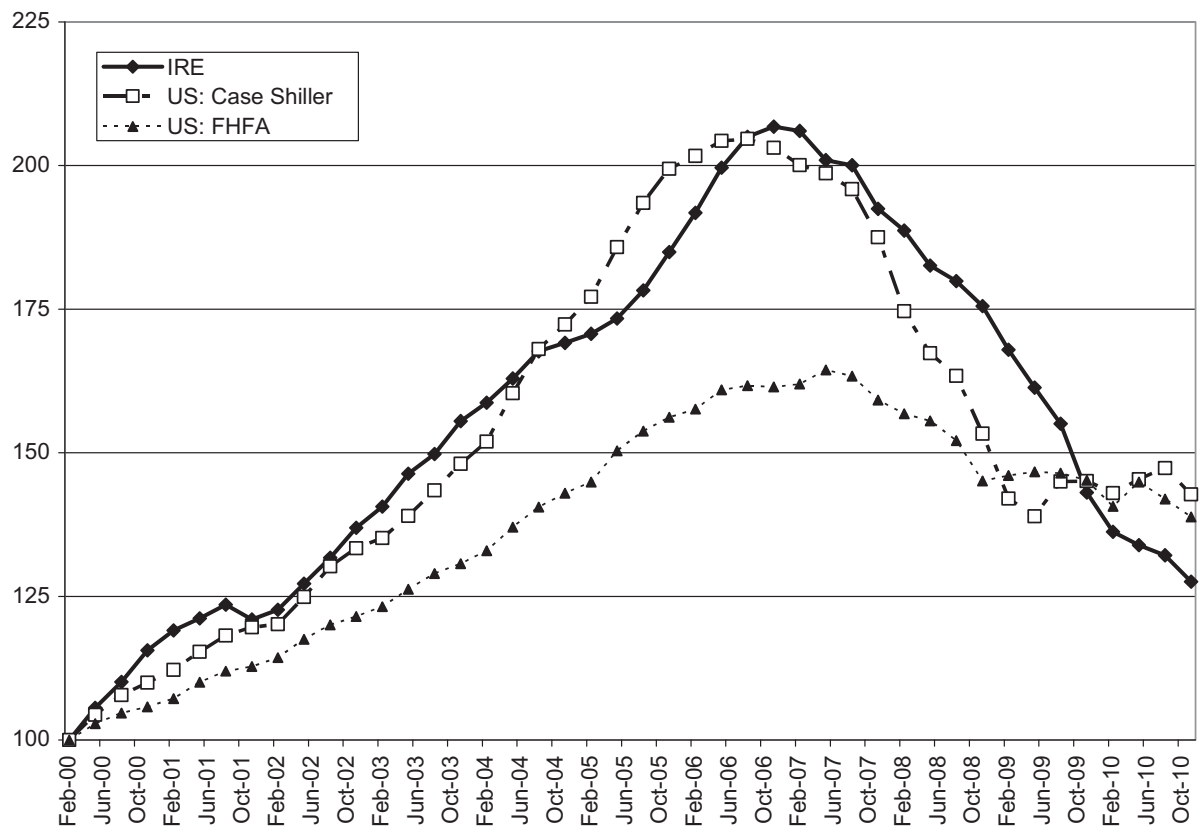

Fig. 4. Irish vs US house prices - 2000-2010. 


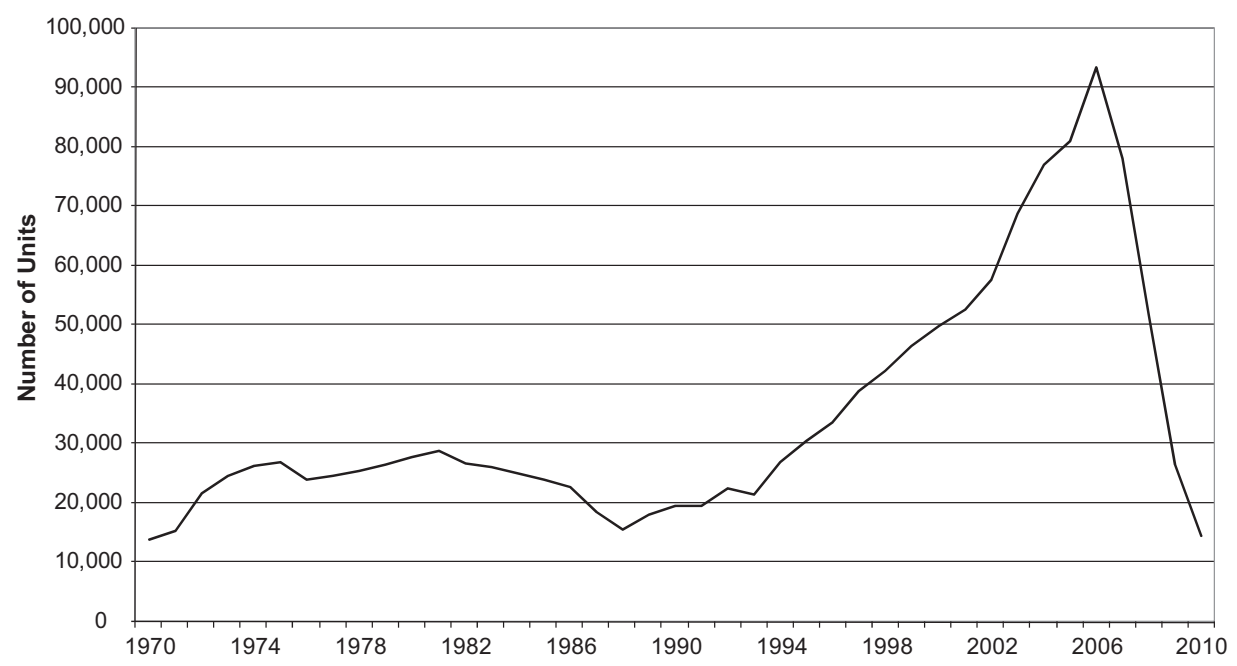

Fig. 5. Irish house completions - 1970-2010.

pre-existing rural dwellings and undoubtedly contributed to the greater price appreciation in the 'second-hand' relative to the 'new' housing market (see Fig. 3).

\section{Capital flow bonanza}

According to Reinhart and Rogoff (2009), a common feature in banking crises is a sustained surge in capital inflows in the run-up period before the crisis. Reinhart and Reinhart (2008) call this a capital flow bonanza and we follow their terminology. They show that the probability of a banking crisis conditional on a capital flow bonanza in the preceding period is substantially higher than the unconditional probability. The US and Irish crises share the common feature of a capital flow bonanza in the periods prior to their credit crises. However, it is notable that this capital bonanza took quite different forms in the two cases.

In the US, large current account deficits throughout the run-up period were offset by large capital account surpluses, with foreign funds flowing into US government debt securities and into mortgagebased securitized assets. Net capital inflows into the USA grew strongly throughout the 2000-2006 period before slowing in the second half of 2007 and reversing to a net outflow in the second quarter of 2008, see St. Louis Federal Reserve (2011). Reinhart and Rogoff (2008b) show that countries experiencing banking crises tend to have large, sustained current account deficits during the pre-crisis runup period. The U.S. had this experience in the period prior to the crisis.

The Irish boom had two distinct phases; namely the Celtic Tiger era of 1997-2002 and a later bubble period, 2003-2007. Capital inflows during these growth episodes are presented in Fig. 6. The former period saw a growth in foreign direct investment (FDI) inward investment and a reduction in the proportion of equity and debt liabilities employed. In contrast, the later bubble period saw a decline in FDI and a clear substitution with foreign capital in the form of debt and equity funding. An important difference between those two episodes is that the Celtic Tiger saw an accumulation of real assets and investments that conferred long-term benefits on the economy, while the bubble era resulted in financial assets that were easily reversible and quickly withdrawn during the economic downturn. A similar story emerged from the Asian crisis of 1997-98 where Taiwan, a country that had successfully attracted FDI investment, fared far better than many of its neighbours who had resisted FDI investment and instead accessed foreign capital in the form of debt and equity investment, e.g. Korea. As the crisis escalated, equity investors withdrew their capital, while FDI investors remained in the region (see Flavin and Panopoulou, 2009 and references therein). 


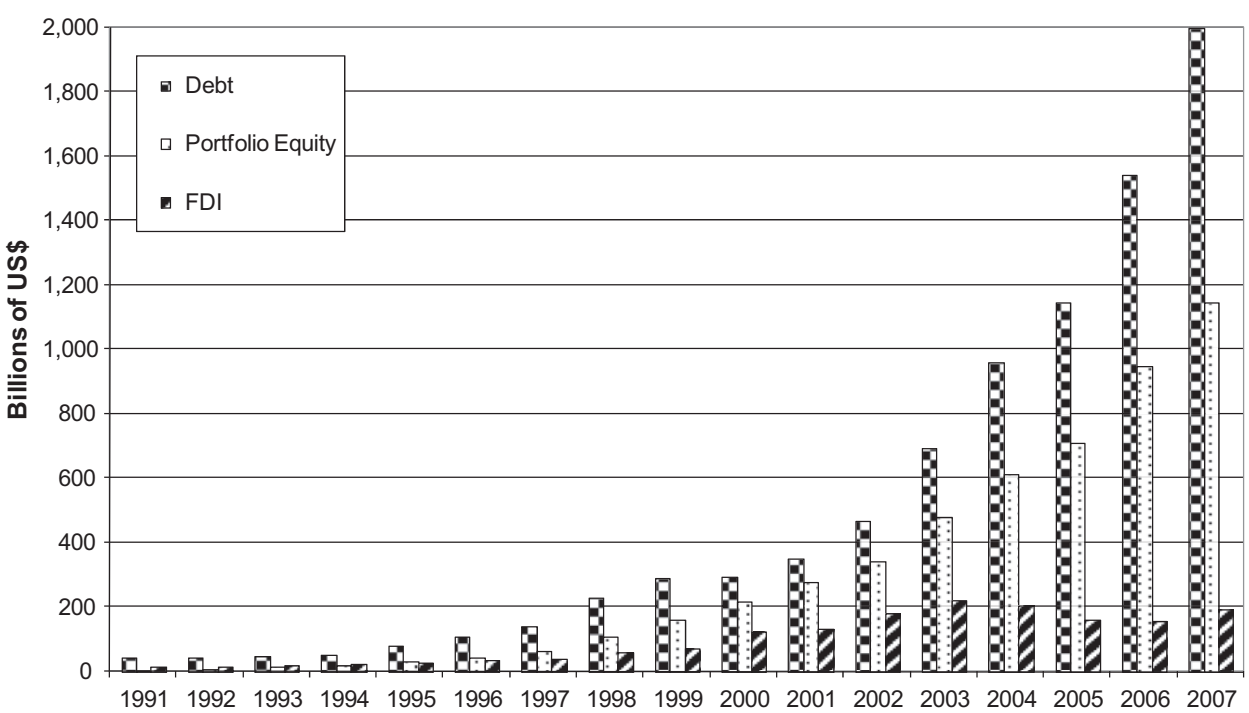

Fig. 6. Irish capital liabilities - 1991-2007. Source: Updated and extended version of the External Wealth of Nations Mark II database developed by Lane and Milesi-Ferretti (2007).

During the bubble period, the Irish capital bonanza was mediated by the domestic commercial banks. In 1999, Irish banks were funded primarily from domestic sources; see Table 1. By 2008, Irish customer deposits provided just $22 \%$ of domestic bank funding. Over $37 \%$ of the funding was obtained in the form of deposits and securities from the international capital markets. Though admittedly starting from a very low base, international sources of funds grew a hundred fold in the period 19992008 and this substantial capital inflow helped the balance sheets of the Irish banks to increase more than six-fold over the same period. Fig. 7 contrasts the liabilities of the banking sector in 1999 and 2008. On the back of this, lending to the non-financial private sector had grown to more than $200 \%$ of GDP by end of 2008, approximately twice the European average. At the time of writing, the most recent data (to May 2010) reveals a modest decline in overall liabilities but interestingly, there is a sharper decline in the proportion of funding sourced in international markets.

In the US, an unusually low real rate of interest and low risk-adjusted required rates on risky investments was a significant feature of this period, related to the capital bonanza. US monetary policy was notably accommodative during the US pre-crisis period; Taylor (2008) argues that this was the main causal factor of the US crisis. In an interesting parallel, a significant factor in the creation of the Irish property bubble was the low interest rates imposed on Ireland following Ireland's admission to

Table 1

Composition of Irish banking liabilities, 1999, 2008 and 2010.

\begin{tabular}{lrrrrrr}
\hline & Dec-99 & Dec-08 & May-10 & Dec-99 & Dec-08 & May-10 \\
\hline Deposits from non-Irish credit institutions & 15,542 & 149,465 & 133,805 & $19.8 \%$ & $29.1 \%$ & $26.1 \%$ \\
Irish customer deposits & 35,142 & 114,235 & 112,491 & $44.8 \%$ & $22.2 \%$ & $22.0 \%$ \\
Deposits from Irish credit institutions & 6472 & 87,196 & 100,345 & $8.2 \%$ & $17.0 \%$ & $19.6 \%$ \\
Other liabilities & 9671 & 57,227 & 59,510 & $12.3 \%$ & $11.1 \%$ & $11.6 \%$ \\
Debt securities - non-Irish & 71 & 43,574 & 34,298 & $0.1 \%$ & $8.5 \%$ & $6.7 \%$ \\
Non-Irish customer deposits & 4336 & 23,415 & 18,083 & $5.5 \%$ & $4.6 \%$ & $3.5 \%$ \\
Debt securities to Irish residents & 241 & 19,092 & 24,982 & $0.3 \%$ & $3.7 \%$ & $4.9 \%$ \\
Capital and reserves & 6990 & 19,746 & 28,550 & $8.9 \%$ & $3.8 \%$ & $5.6 \%$ \\
& & & 512,064 & $100.0 \%$ & $100.0 \%$ & $100.0 \%$ \\
\hline
\end{tabular}

Source: Central Bank and Financial Services Authority of Ireland. Table C4, Quarterly Bulletin. 


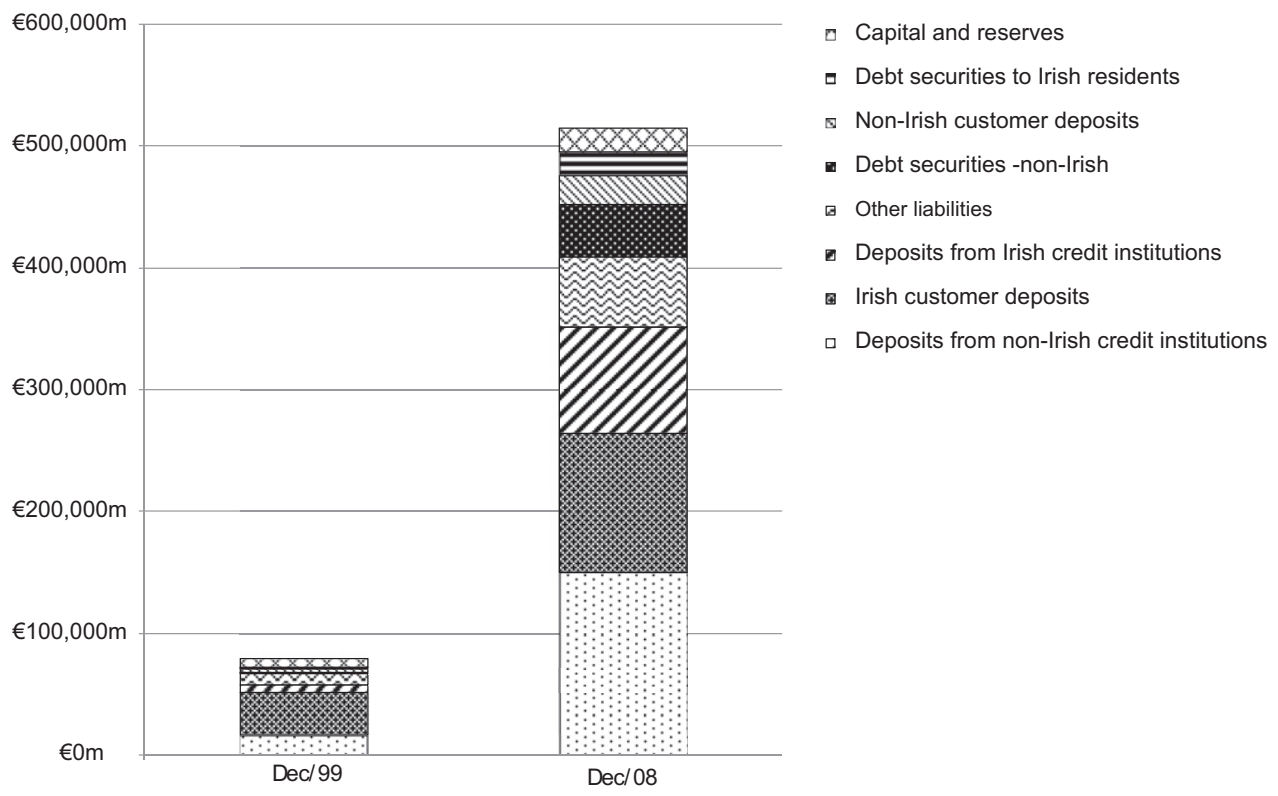

Fig. 7. Composition of Irish banking liabilities, 1999 and 2008.

the Euro currency union. As a small country operating within a monetary union, Ireland suffered from the one-size-fits-all approach to monetary policy, as the Irish business cycle was generally asynchronous with that of its European neighbours. As noted above, Ireland maintained a high rate of economic growth over the period from 1995 to 2005, with growth substantially higher than the Eurozone average. With nominal interest rates set by the European Central Bank (ECB) to cater for the entire Eurozone, and exchange rates fixed within the Eurozone, Ireland had great difficulty maintaining its inflation rate within the range demanded by the criteria set down in the creation of the single currency. An inflation rate that was above the EU average, together with low nominal rates set by the ECB, meant that during the pre-crisis period Ireland had very low, mostly negative, real interest rates. The ECB policy rate was less than Irish inflation rate for most of the ten years prior to the crisis (see Fig. 8).

After Ireland's entry to the Eurozone, Irish banks funded much of their lending with short-term foreign borrowing. This allowed Irish financial institutions to extend much larger volumes of credit to borrowers at lower cost, as evidenced by Fig. 8. As a small member of the Eurozone, Ireland does not have sole control of its interest rates, but Fig. 9 shows a hypothetical Irish-only target rate calculated from a standard Taylor rule. We set the target rate equal to $1 / 2$ (GDP growth rate $-3 \%$ ) $+1 / 2$ (inflation rate $-2 \%)+1 \%$. Had Eurozone interest rates been set in accordance with a Taylor rule for Ireland, the interest rate would have been almost 6 percentage points higher on average during the period and up to 12 percentage points higher in 2000.

\section{Regulatory imprudence}

An important common feature of the two crises was regulatory imprudence. In both countries, policymakers and regulators allowed the risk profiles of their financial services sectors to evolve in very dangerous ways, influenced by strong domestic political pressures. Interestingly, the nature of the political pressures that swayed policymakers in the two countries was quite different, and the detailed nature of the policy and regulatory errors was also dissimilar. 


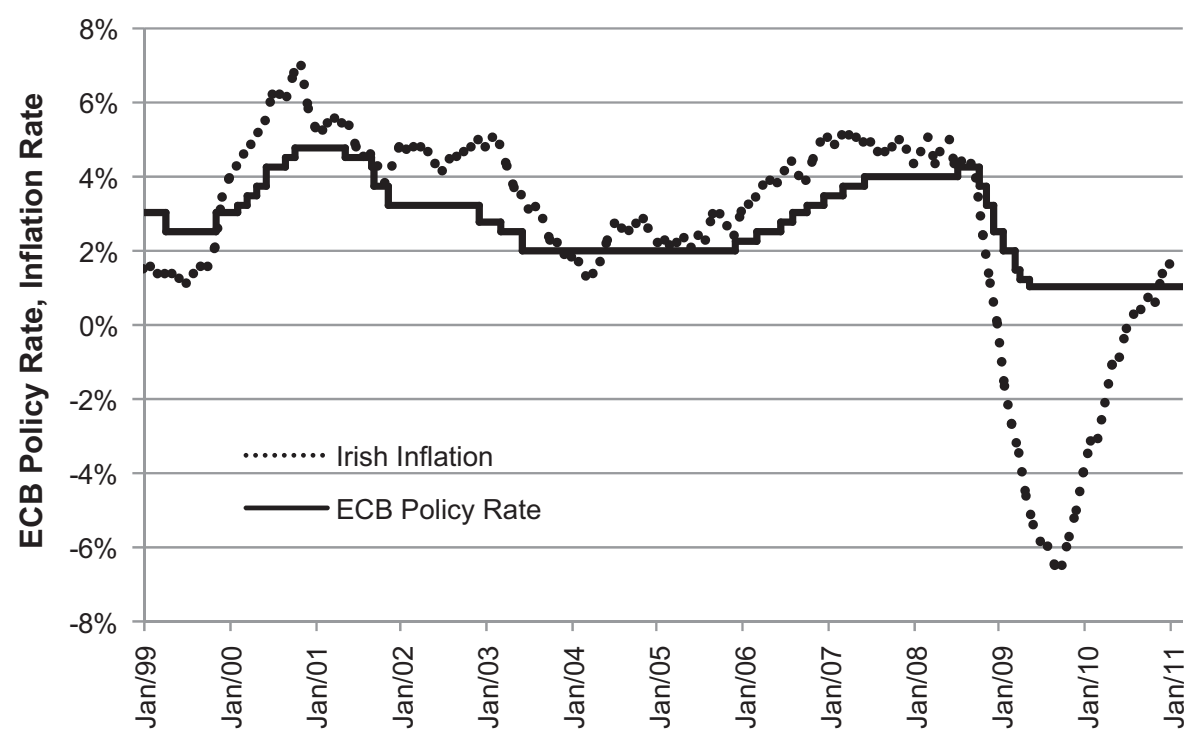

Fig. 8. Irish inflation rate and ECB policy rate: 1999-2010.

The seeds of the U.S. crisis lie in the subprime mortgage market. It is important for comparative purposes to note that this market is almost uniquely American. The subprime mortgage market serves a politically important role in U.S. housing policy. In effect, it supplements or replaces the burdensome government expenditures on social-housing programmes that are common in other developed nations

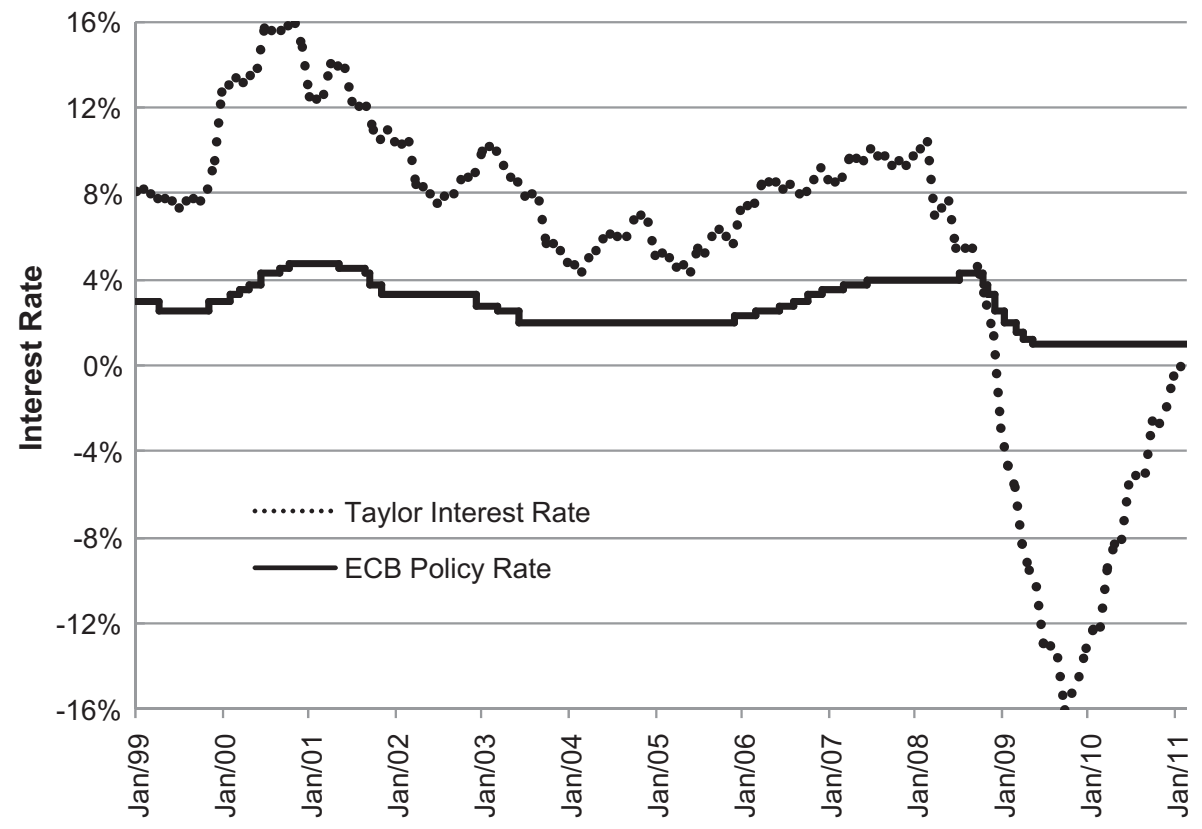

Fig. 9. Taylor rule rates for Ireland and ECB policy rate: 1999-2010. 
(including Ireland). During the Bush administration, the social goal of broadening home ownership through subprime lending was very successful. In March 2000, Fannie Mae announced its American Dream Commitment: an aggressive corporate strategy to purchase $\$ 2$ trillion in mortgage loans for poor and minority households over the following ten years. The period 2000-2007 saw a strong trajectory towards meeting this target. Home ownership in the US grew from $64 \%$ in 2004 , where it had been for almost two decades, to $69 \%$ in 2007, a spectacular increase of 5 percentage points in five years, with particularly high rates of increase among Blacks and Hispanics. From the perspective of increasing home ownership as a political and regulatory goal, the pre-crisis period was an outstandingly successful period. However, to quote Shiller (2010):

"Encouraging homeownership is a worthy and admirable national goal. It conveys a sense of participation and belonging, and high homeownership rates are beneficial to a healthy society. ... But the subprime housing dilemma in the United States points up problems with over-promoting homeownership. Homeownership, for all its advantages, is not the ideal housing arrangement for all people in all circumstances. And we are now coming to appreciate the reality of this ..."

Analysts now accept that during the pre-crisis period the securitized mortgage market grew excessively. This excessive growth can be traced, at least in part, to political pressures (Issa, 2009). Many subprime borrowers had poor-credit histories and undocumented income. They lacked the two essential ingredients normally demanded of borrowers: a substantial down payment and a verifiable source of steady income to meet the ongoing repayments.

Securitized subprime mortgages represented an American solution to the social problem of providing low-income housing. Securitization was viewed as a positive development which gave the benefits of credit risk diversification and the expansion of trading opportunities. The consequent increase in moral hazard problems (discussed in the next section) was downplayed or ignored. Reinhart and Rogoff (2009) refer to the "this time is different" cognitive error, in which economic agents convince themselves that new technologies have eliminated traditional sources of financial risk. This type of cognitive error was clearly a feature in regulatory and managerial responses to the enormous growth in mortgage-related securities markets during the early years of the new century. With hindsight, the diversification benefits seem to have been exaggerated due to the similarity of the securitized products and the credit and liquidity risks arising from cross-holdings of assets by large financial institutions. Many of these products were so complex that much of the cross-holdings may have arisen not by construction but inadvertently. Kiyotaki and Moore (2002) argue that high correlations may arise through interlinkages which are not at first apparent to the market due to their complexity.

In the US, in addition to political pressure to increase home ownership, there was purely selfinterested lobbying by business interests involved in the lucrative mortgage securitization process and in mortgage-security-related trading. ${ }^{4}$ Igan et al. (2009) find evidence of attempts at regulatory capture in the U.S. They find that the lenders who lobbied most intensively on specific issues related to mortgage lending were those who originated mortgages with higher loan-to-value ratios, securitized a faster-growing proportion of their loans and had faster-growing loan portfolios. They suggest that lobbying was linked to lenders expecting special treatments from policymakers, allowing them to engage in riskier lending behaviour. They further suggest that lending behaviour was affected by the politics of special interest groups. Dell'Arriccia et al. (2008) present evidence that lending standards declined in regions where the credit boom was larger, that lower regional lending standards were associated with a faster rate of house price appreciation, and lending standards declined more in regions where new competitors entered the market and where a larger proportion of loans was securitized.

In Ireland as in the USA, political pressures skewed the financial regulatory setting, but in very different ways. Starting in the early 1990s, the Irish government made a strategic decision to become

\footnotetext{
${ }^{4}$ In his commentary on an earlier version of our paper, Krugman (2010) argues that the purported US political pressure for increased home ownership was more feigned than real and that lobbying by business interests was a more important factor in skewing US regulatory policies.
} 
a world-leader in "offshore" financial services. For foreign financial services firms willing to set up operations in Ireland, the main attractions were an educated, English-speaking workforce, a Western European location, and light-touch, almost nonexistent, tax and regulatory oversight. This very lax supervisory regime led The New York Times to call Ireland "the wild west of European finance."5

An unintended consequence of the extremely light-touch financial regulatory regime in Ireland was to hobble Irish regulators in their oversight of domestic banks. The actions of the Irish financial regulator during this period were secretive with limited public disclosure. In a 2009 appearance before the Irish parliament, the newly appointed head of the Irish Central Bank called for an official investigation into bank regulation during the pre-crisis period, modelled on the US Financial Crisis Inquiry Commission. At present, most of what is known was revealed inadvertently or through leaks to the media. Ross (2009) conducts an investigative study and argues that the regulatory regime for domestic Irish banks during the pre-crisis period was extremely weak and ineffective. As Ross recounts, the only aggressive actions of the Irish financial regulator seemed to be directed at media leaks; its relationship with the financial services sector was very accommodating and compliant. For example, for eight years, the board chairman and other directors at Anglo Irish Bank hid very large personal loans by temporarily transferring them just prior to accounting year-end to other banks complicit in the scheme, and then by pre-agreement rolling the loans back into Anglo Irish immediately after the publication of the annual accounts. It is not yet clear $^{6}$ whether the regulator approved, ignored, or missed this subterfuge, but no regulatory action was or has been taken. Also, Anglo Irish Bank deliberately understated its loans-to-deposits ratio through sham transactions - this took the form of agreed interbank lending by Anglo to another Irish domestic bank just before reporting year-end, and then immediately accepting the funds back from the other bank as "customer savings deposits." In this case there is considerable evidence (obtained via media leaks) that the Irish financial regulator informally approved of the stratagem. ${ }^{7}$ In 2007, Anglo Irish became aware that a large shareholder was preparing to sell a $10 \%$ position in Anglo Irish shares. To prevent this share sale from impacting its share market price, Anglo senior management organized a secret circle of ten wealthy bank clients, lent each of them $€ 30$ million for the purchase of Anglo shares, with limited recourse on the loans beyond the purchased shares as collateral. Since the loans were with limited recourse to the borrowers, Anglo was the at-risk investor in the shares, and was essentially using $€ 300$ million of its depositors' funds to secretly purchase its own equity shares. Again, there have been no prosecutions, and there is (disputed) evidence that the financial regulator was at least dimly aware of this share manipulation scheme. ${ }^{8}$

In addition to ignoring, or even condoning, fraudulent accounting, the financial regulator and Irish central bank made strategic errors in not responding to the build-up of systemic risk to the banking system. Honohan (2009) provides a careful analysis of the major policy errors by the Irish financial regulator and Irish central bank during the pre-crisis period. He notes that rapid balance-sheet growth of financial institutions - usually interpreted as growth of more than $20 \%$ per annum in any year - is a basic warning sign used by financial regulators. The balance sheets of Anglo and Irish Nationwide expanded by an average of 36\% and 20\% per year over the ten-year period from 1998 to 2007. Honohan argues that, using standard procedures, the Irish financial regulator should have acted on the systemic risk generated by these extremely high balance-sheet growth rates. Furthermore, the overly concentrated focus of the banking sectors' lending activities on property development should have been acted upon. In addition to inadequately responding to system-wide distortions, the Irish regulator overlooked obvious distortions in the risk profiles of individual banks. For example, Irish Nationwide was a building society established to provide mortgages to its members. Yet it was allowed by the regulator to put its members' funds at risk by lending $80 \%$ of its funds to a small number of property developers. By 2006, only a small proportion of its loan book consisted of retail mortgages; although providing these retail mortgages was its purported institutional mission.

\footnotetext{
${ }^{5}$ Lavery and O'Brien (2005).

6 See Weston (2009).

7 See Lord (2009).

${ }^{8}$ See O’Brien et al. (2009) and Oliver (2009).
} 
The dramatic growth in lending to the Irish residential property sector was fuelled partly by looser lending criteria. As Anglo Irish Bank and Irish Nationwide pursued very aggressive lending policies, more traditional banks responded by being more accommodating to potential borrowers. Increasing rivalry between institutions for market share is cited as a reason for the parallel decline in standards; see Honohan (2009).

Although the major sources of systemic risk were the overuse of interbank borrowing and the overconcentration on very risky property development loans, the credit quality of new residential mortgages in Ireland also declined substantially during the run-up period. Fig. 10 shows that more mortgages were for higher loan-to-value; the percentage of mortgages for greater than $95 \%$ of the property value increased from $6 \%$ to $16 \%$ in the period 2004-2007. Likewise, Fig. 11 shows that the maturity of the mortgages lengthened, with the percentage of loans with a maturity of greater than 30 years jumping from $10 \%$ to $35 \%$ in the period $2004-2007$.

Woods (2007) reports that, as a proportion of lending to the private sector, property-related lending grew from $38 \%$ in 2001 to over $62 \%$ in 2007 . With the enormous growth in property- and constructionrelated lending, the loan books of Irish domestic banks were becoming increasingly undiversified. While commercial property prices continued to surge up to 2006, rental income did not follow suit. This resulted in low-income yields in Ireland relative to European neighbours. Consequently, investors in this sector were relying heavily on capital gains for their prospective returns.

Another source of regulatory imprudence in Ireland was the long and close relationship between the Fianna Fáil political party (the dominant party in coalition governments during most of the pre-crisis period) and the Irish property development industry; see MacDonald and Sheridan (2008) for a detailed discussion. Also, the public exchequer was becoming ever more reliant on taxes from this sector. The tax take from stamp duty on the purchase of property was, at the peak of house prices in 2006, accounting for about $17 \%$ of all tax revenues. When one adds on the income tax paid by construction workers and value-added tax collected on property sales, the industry was contributing about one-fifth of all government tax revenue. The government did not have the political will to dampen the sector.

In addition to the enormous credit inflow discussed in the previous section, the over-heating of the Irish property market was exacerbated by government legislation that encouraged people to invest in property through a series of tax-incentive schemes. For example, generous tax relief was available to investors in hotels as the government sought to increase the stock of hotel rooms and hence tourism; similar breaks were available to individuals who built houses in seaside towns and in rural areas. The stated aim of these programmes was to instigate 'rural regeneration', but there is little available evidence that they delivered sustainable benefits to the sparsely populated regions earmarked by the

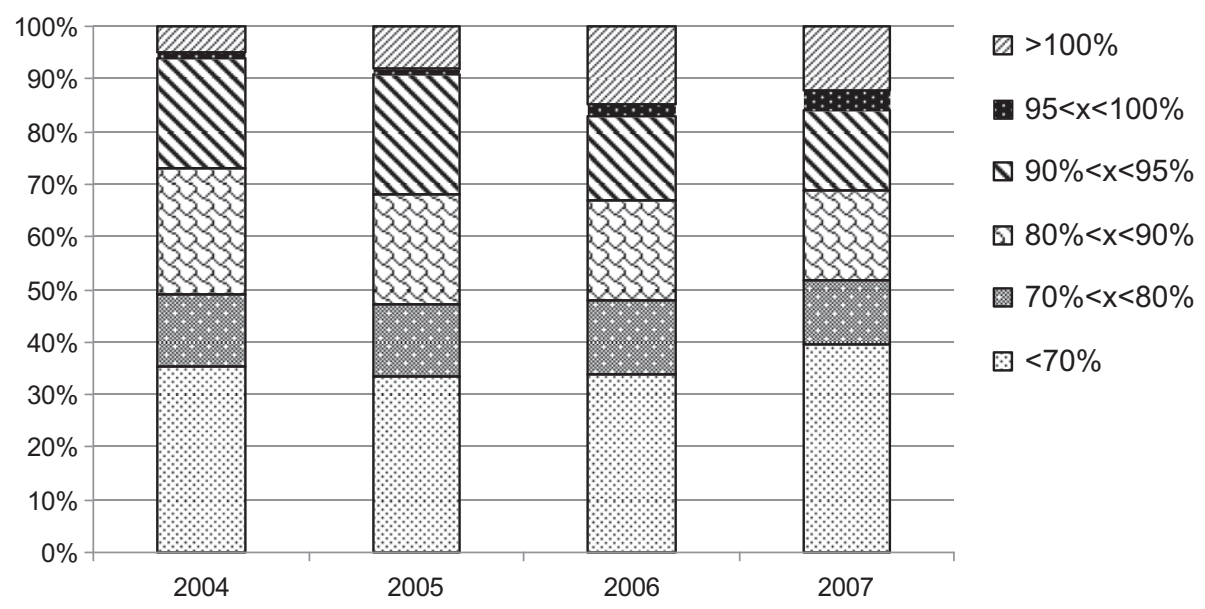

Fig. 10. Composition of Irish mortgages by loan-to-value: 2004-2007. 


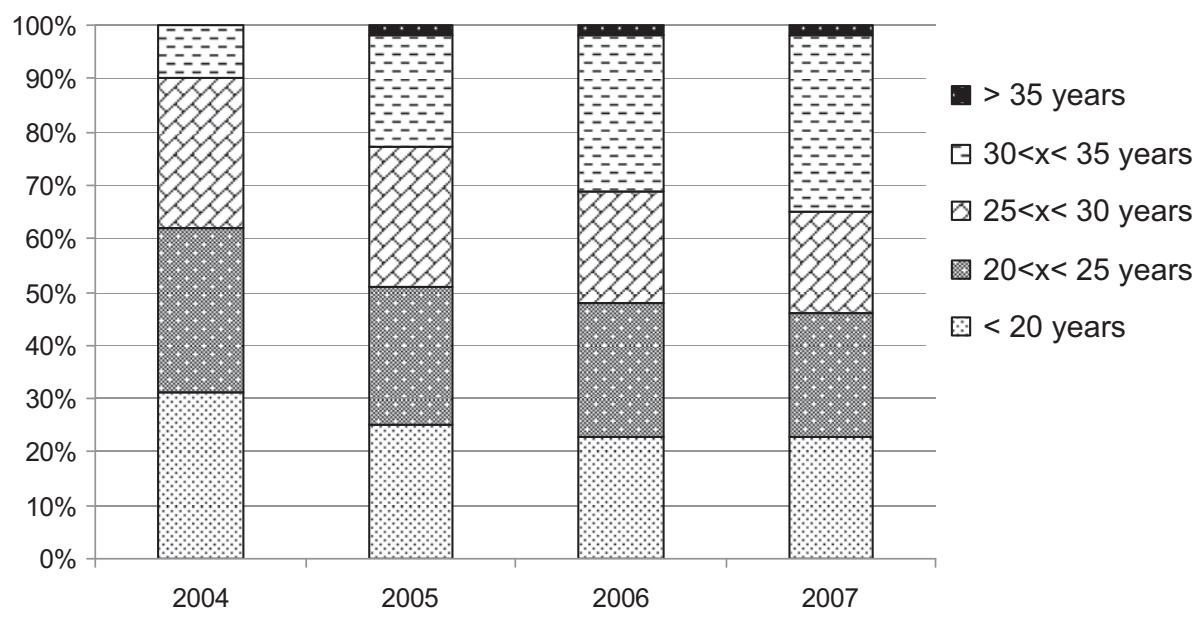

Fig. 11. Composition of Irish mortgages by loan maturity: 2004-2007.

programmes. Following the crisis, Ireland struggled with an enormous glut of hotel rooms and newlybuilt, vacant rural housing.

As fears for the health of domestic banking systems gripped many countries, the Irish sector was initially quite bullish about the ability to remain outside of the global turmoil. The chief financial regulator, Patrick Neary, assured concerned parties in September 2008 that it is “...important to point out that Irish banks have only very limited exposures to US subprime losses and related credit products." While this statement was true, it missed the Irish economy's over-dependence on a domestic property market bubble. He went on to say: "Irish banks are resilient and have good shock absorption capacity to cope with the current situation."

As mentioned above, a considerable decline in lending standards occurred in the Irish mortgage market; an increasing proportion of lending was done at higher loan-to-value, higher income multiples, longer maturities, and with interest-only periods. The only step the regulator took to stem the decline in lending standards was to increase to $100 \%$ the risk-weighting on the portion of a residential mortgage written above an $80 \%$ loan-to-value threshold. As Honohan (2009) notes, this was a weak and ineffective response.

In summary, regulators and policymakers in both countries made erroneous decisions in response to political pressures. The specific nature of the errors, and the types of pernicious political influences, differ substantially in the two cases. Another notable distinction is in the nature of the regulatory policy errors in the two jurisdictions. US regulators (along with a substantial proportion of the economics research community) failed to appreciate the dangerous fragility of the extremely complex interactions linking several technically sophisticated US financial markets. The economic research community is now building theoretical models which explain the ensuing credit-liquidity gridlock. In contrast, in Ireland, the regulatory mistakes were simple misjudgements, obviously flawed relative to standard regulatory procedures widely available at the time.

\section{Moral hazard}

Moral hazard occurs when an agent has an incentive to take economically inefficient actions because the agent is insulated from the risky consequences of his behaviour. Moral hazard problems played a big role in both the US and Irish crises, but in quite different forms.

As discussed in Section 2, the US credit-liquidity crisis had its origin in a large increase in the stock of poor- quality mortgages in the USA during 2000-2006. This unsustainable increase in low-creditquality mortgages can be traced back, at least in part, to the severe moral hazard problems in the 
originate-and-distribute mortgage-generation system dominant in US banking. Under this system, mortgage originators sell mortgage loan assets on to other parties who then securitize them and re-sell them in packaged form. Mortgage originators have little or no incentive to monitor credit quality of individual mortgages or to rigorously enforce purported credit standards since they are insulated from all credit-related losses once the mortgages are sold. Dell'Arriccia et al. (2008) demonstrate convincingly that this moral hazard problem contributed to the decline in mortgage credit quality in the US during 2000-2006. They show that the relative credit quality decline during this period was highest in regions with the highest proportion of securitized mortgages (op. cit. Section V.F, Table 12). Rajan et al. (2008) show that as the percentage of securitized loans increased in regional areas, loan originators created a bias in the perceived credit quality by substituting "hard" credit information on borrowers (information which could be documented and used in the securitization process) at the expense of "soft" information about the true credit quality of individual borrowers. In a related paper, Keys et al. (2008) show that loan originator laxness in screening mortgage applicant credit quality is directly related to the probability that a given loan will be securitized. See also Diamond and Rajan (2008) on the importance of the mortgage credit quality decline, caused by the originate-and-distribute lending system, as a causal factor in the ensuing US credit-liquidity crisis. Despite its centrality to the US crisis, this particular moral hazard problem has no relevance to the Irish credit crisis. Throughout the precrisis period Irish banks used the originate-and-hold lending system, for both residential mortgage and business lending. Almost all the loans that the Irish banks generated remained on their own balance sheets. This crucial component of the US crisis is virtually absent in the Irish case.

A moral hazard problem associated with performance-related-pay in the financial services industry was another key driver of the US crisis. Kashyap et al. (2008) note that the imperfections linking management true performance and long-run share value mean that managers are over-incentivized to hold "tail risk" - essentially, traders are incentivized to have a portfolio or trading strategy earning a reliable stream of modest insurance-premium-like income in exchange for accepting (on behalf of their firm) a small-probability risk of a very large loss. If, during the career of a trader, a negative tail event is realized, he/she can exercise his/her "trader put option" and resign from the firm (or be fired), leaving firm shareholders to cover the large loss. ${ }^{9}$ This loss truncation in performance-related-pay is a moral hazard problem since the trader is insulated from the risky consequences of his actions and this adversely affects his incentives to avoid excessive risk. The return distribution feature of frequent modest profits plus infrequent negative tail risk fits the return distribution of mortgage-related securitized assets and mortgage credit derivatives. Franke and Krahnen (2008) argue that the misaligned incentives in financial-management compensation, along with the moral hazard problem of loan originators in the originate-and-distribute loan generation system, were the two basic underlying causes of the US crisis. Brunnermeier (2009) shows that the incentive for excessive risk-taking by investment managers is worsened by a low-interest-rate environment. Unusually low interest rates characterized the pre-crisis periods in both countries. On a separate but related point, Agarwal and Wang (2009) show that performance-related compensation for middle managers in the US mortgage-generation industry also contributed to the decline in average credit quality.

The moral hazard problem associated with loss truncation in performance-related compensation in financial services also has relevance in the Irish case. As discussed earlier, Irish banks borrowed cheaply in the interbank Euro market and invested these borrowed funds in loans to domestic property developers. On the one hand, the risk-return distribution of this very risky strategy does not have the classic "tail risk" pattern of securitized mortgage assets and related credit derivatives. On the other hand, when the strategy went badly wrong, the "trader put option" was successfully exercised by many senior executives in the Irish domestic banks. Recall from Section 2 above that there were two rogue institutions, Anglo Irish Bank and Irish Nationwide Building Society, who stoked the fires of the bubble with particularly reckless lending practices. Each of these institutions was controlled by a single, powerful and long-standing chief. When the magnitude of the bad loans at the two institutions became clear, along with a host of accounting and share trading irregularities, both of these bank heads were

\footnotetext{
${ }^{9}$ Admittedly the reputation and future earnings of the trader will be hurt but the financial losses fall on shareholders and/or domestic taxpayers in the event of a government bailout.
} 
forced into retirement. The two rogue-bank heads retired with their large fortunes intact, and there is little or any hope of financial recourse by taxpayers or others.

Of course, both the US poor-credit-quality mortgages and Irish risky property development loans involved conscious decisions by borrowers as well as lenders. In the case of poor-credit-quality US mortgages the borrowers were individual households with relatively low incomes. The property loans issued by Irish banks were obtained by wealthy property developers, arguably well-informed, rational actors with considerable business acumen. It is not clear whether a moral hazard argument can explain their behaviour. Personal guarantees were a standard component of property development loan contracts in Ireland during the pre-crisis period, so most of these developers did not have recourse to the trader put option. Irish property developers are legally liable for the "tail risk" in the net value of these loans, including de jure claims against their personal assets.

This brings us to another potential contributor factor to the moral hazard problem in the Irish case: weak law enforcement. The legal framework for personal bankruptcy in Ireland is antiquated and rarely activated. Although property developers signed de jure claims against their personal assets as part of their bank loan contracts, many commentators believe that these claims are de facto unenforceable in Ireland. There is also the concern in Ireland that politically powerful agents have the ability to manipulate regulatory and legislative processes to avoid liability for large losses. Most large property developers in Ireland have been very closely connected to the largest ${ }^{10}$ political party, Fianna Fáil. Kelly (2009) uses the term "too connected to fail" for this feature of the Irish business environment; referring to political connections rather than banking linkages.

With regard to weak law enforcement, the situation in Ireland is dramatically different from that in the USA, where corporate, financial regulatory, securities and bankruptcy laws are enforced with unusual strictness and severity by international standards. This is another distinctive difference between the two crises.

There are other moral hazard problems statistically linked to financial crises which may or may not have had some role in the two cases under consideration here. Moral hazard problems associated with bank deposit insurance have been exhaustively studied. On the one hand, deposit insurance is a powerful tool in preventing bank runs. On the other hand, guaranteed liability holders have no incentive to monitor bank riskiness or to shift their deposits (or other insured liabilities) away from errant banks. This gives banks and other financial institutions a moral hazard incentive to increase the riskiness of their balance sheets unduly. Moral hazard behaviour associated with deposit insurance is widely assigned a large role in the US savings and loan crisis of the early 1980s, e.g., Keeley (1990). It had no obvious role in the more recent US crisis. Attention has shifted towards the implicit liability guarantees which will exist whenever the ex post optimal government response to an existing crisis would be to insure or save large, ailing financial institutions, the "too big to fail" problem. Some commentators argue that the U.S. government's decision to step in and save Bear Sterns worsened the magnitude of the ensuing crisis since it led other financial services firms to believe that they had an implicit bailout guarantee and could act accordingly, e.g., Cohan (2010).

Did the moral hazard associated with liability guarantees or bank bailouts have an influence on Irish bank behaviour? During the pre-crisis period, Irish banks had access to only limited governmentsupported deposit insurance. However, the government's first action after the Lehman Brothers collapse was to institute with immediate effect a government-funded blanket guarantee of all domestic Irish banks' liabilities. The Irish government's ex post guarantee even covered equity holders since, as mentioned earlier, as the banks' core equity capital deteriorated, the government supplied equity capital directly to the banks. It also set up the National Asset Management Agency whose remit to pay "the long-term economic value," as opposed to current market value, for distressed property loans helped to keep the privately owned equity capital in the banks from collapsing to zero.

Ex post, Irish domestic banks were blessed with extremely generous bailout policies by the government. Was this "implicit guarantee" foreseen by the banks ex ante, and did this affect their behaviour? For the two largest Irish domestic banks, there was probably some foresight that if their

\footnotetext{
${ }^{10}$ In a dramatic fall from grace, the Fianna Fáil party suffered an historic loss in the February 2011 national elections, falling to third place among parties in voting percentage; this occurred after the period under discussion here.
} 
reckless actions during the pre-crisis period led them into trouble, the government would step in and save the institutions. This certainly turned out to be the case, and such an outcome seems predictable ex-ante. So the "too big to fail" implicit guarantee moral hazard problem seems relevant to the Irish crisis, with "too big to fail" recalibrated to the small absolute size of the Irish banking system.

In summary, moral hazard problems played a big role in both crises, but in surprisingly different forms. The moral hazard problem in the originate-and-distribute mortgage system played a central role in setting the stage for the US crisis. This market feature was almost entirely absent in Ireland where an originate-and-hold loan generation system was dominant. The moral hazard associated with loss truncation in performance-related-pay had a role in both the US and Irish crises. Weak law enforcement was another source of moral hazard in Ireland, but this does not apply in the USA where the enforcement of corporate and financial regulatory law and personal bankruptcy law is unusually strict by international standards. Whether the moral hazard problems associated with financial firm bailouts had an important role in the two crises is difficult to discern with any confidence.

\section{Summary and conclusions}

The US credit-liquidity crisis of 2007-08 and the subsequent Irish credit crisis were nearly contemporary, and also have some causal connections, since reverberations from the US crisis precipitated the Irish crisis. Nonetheless, at a superficial level they are surprisingly different. This paper explores the similarities and differences between the two crises. We identify four broadly defined common features in the causal foundations of the two crises. The four common features are asset price bubbles, capital bonanzas, regulatory imprudence, and moral hazard. Looking in more detail at each of these four common features, we find that their particular manifestations are quite different in the two crises.

This modest two-crisis comparison cries out for more research. Are the four common features that we identify present in a broader sample of financial crises in recent decades? Are there additional common features that we have missed, or alternative taxonomies? We find in our comparison of the US and Irish crises that the particularities of the crises are very different. In a broader sample of crises, is there a similar diversity in the specific causal mechanisms generating the crises?

\section{References}

Aït-Sahalia, Y., Andritzky, J., Jobst, A., Nowak, S., Tamirisa, N., 2009. How to Stop a Herd of Running Bears? Market Response to Policy Initiatives During the Global Financial Crisis. Working Paper. IMF. WP/09/204.

Agarwal, S., Wang, H., 2009. Perverse Incentives at the Banks? Evidence from a Natural Experiment. Working Paper. Federal Reserve Bank of Chicago.

Brunnermeier, M., 2009. Deciphering the liquidity and credit crunch 2007-08. Journal of Economic Perspectives 23 (1), 77-100.

Brunnermeier, M., Pedersen, L., 2009. Market liquidity and funding liquidity. Review of Financial Studies 22 (6), $2201-2238$.

Cabellero, R., Krishnamurthy, A., 2008. Collective risk management in a flight to quality episode. Journal of Finance 63 (5), $2195-2229$.

Cohan, W., 2010. The three magi of the meltdown. The New York Times January 7.

Coval, J., Jurek, J., Stafford, E., 2009. The economics of structured finance. Journal of Economic Perspectives 23 (1), 3-25.

Craig, S., Smith, R., Ng, S., 2008. Merrill aims to raise billions more: firm dumps mortgage assets as crisis drags on. Wall Street Journal July 29th.

Dell'Arriccia, G., Igan, D., Laeven, L., 2008. Credit Booms and Lending Standards: Evidence from the Subprime Mortgage Market. Working Paper. IMF.

Diamond, D., Rajan, R., 2008. The Credit Crisis: Conjectures about Causes and Remedies. Working Paper. University of Chicago School of Business, Chicago, IL.

Dwyer, G., Tkac, P., 2009. The financial crisis of 2008 in fixed income markets. Journal of International Money and Finance 28 (8), 1293-1316.

FitzGerald, J., 2005. The Irish Housing Stock: Growth in Number of Vacant Dwellings. Quarterly Economic Commentary. Economic and Social Research Institute, Dublin.

Flavin, T.J., Panopoulou, E., 2009. Dealing with East Asian equity market contagion: some policy implications. In: Gregoriou, G. (Ed.), Emerging Markets: Performance, Analysis and Innovation. Chapman-Hall/CRC/Taylor \& Francis, London, pp. 475-492.

Franke, G., Krahnen, J., 2008. The Future of Securitization. Working Paper \#2008/31. Center for Financial Studies, Goethe University, Frankfurt, Germany.

Gorton, G., 2008. The Panic of 2007. Working Paper. Yale ICF.

Honohan, P., 2009. Resolving Ireland's banking crisis. Economic and Social Review 40 (2), 207-231.

Igan, D., Mishra, P., Tressel, T., 2009. A Fistful of Dollars: Lobbying and the Financial Crisis. Working Paper. IMF.

International Monetary Fund, 2008. World Economic Outlook: Financial Stress, Downturns, and Recoveries. IMF, Washington, DC.

Issa, D., 2009. The role of government affordable housing policy in creating the global financial crisis of 2008. U.S. House of Representatives Staff Report, 111th Congress, Committee on Oversight and Government Reform, July 7.

Kashyap, A., Rajan, R., Stein, J., 2008. Rethinking Capital Regulation. Mimeo. University of Chicago. 
Keeley, M., 1990. Deposit insurance, risk and market power in banking. American Economic Review 80 (5), 1183-1200.

Kelly, M., 2007. On the Likely Extent of Falls in Irish House Prices. Working Paper 07/01. University College Dublin.

Kelly, M., 2009. The Irish Credit Bubble. Working Paper. University College, Dublin.

Keys, B.J., Mukherjee, T., Seru, A., Vig, V., 2008. Did Securitization Lead to Lax Screening?: Evidence from Subprime Loans. Working Paper. London Business School, London.

Kindleberger, C., 1989. Manias, Panics and Crashes: A History of Financial Crises. Basic Books, New York.

Kiyotaki, N., Moore, J., 2002. Balance sheet contagion. American Economic Review 92 (2), 46-50.

Krugman, P., 2010. An Irish mirror. New York Times March 7th.

Lane, P., Milesi-Ferretti, G.M., 2007. The external wealth of nations mark II. Journal of International Economics 73 (2), $223-250$.

Lavery, B., O’Brien, T.L., 2005. For insurance regulators, trails lead to Dublin. New York Times April 1st.

Lord, M., 2009. A nod is as good as a wink to a cornered banker or blind regulator. Irish Times February 25th.

Lowenstein, R., 2000. When Genius Failed: The Rise and Fall of Long-Term Capital Management. Random House, NY, USA.

MacDonald, F., Sheridan, K., 2008. The Builders: How a Small Group of Property Developers Fuelled the Building Boom and Transformed Ireland. Penguin, Ireland.

O’Brien, P., Ryan, C., Rogers, S., 2009. Regulator accepted Anglo's word that $€ 300$ million share deal was above board. Irish Examiner February 18th.

Oliver, E., 2009. Anglo believed financial regulator approved share deal. Sunday Tribune February 22nd.

Rae, D., van den Noord, P., 2006. Ireland's Housing Boom: What has Driven it and Have Prices Overshot?. Working Paper 492 OECD Economic Department.

Rajan, U., Seru, A., Vig, V., 2008. The Failure of Models that Predict Failure: Distance, Incentives and Default. Working Paper. University of Chicago, Chicago.

Reinhart, C.M., Reinhart, V.R., 2008. Capital flow bonanzas: an encompassing view of the past and present. In: Frankel, J., Giavazzi, F. (Eds.), NBER International Seminar in Macroeconomics 2008. Chicago University Press, Chicago IL.

Reinhart, C.M., Rogoff, K., 2008a. This Time is Different: A Panoramic View of Eight Centuries of Financial Crises. Working Paper. NBER \#13882, Cambridge, MA.

Reinhart, C.M., Rogoff, K., 2008b. Is the 2007 U.S. subprime banking crisis so different: an international historical comparison. American Economic Review 98 (2), 339-344.

Reinhart, C.M., Rogoff, K., 2009. This Time is Different: Eight Centuries of Financial Folly. Princeton University Press, Princeton, NJ.

Ross, S., 2009. The Bankers: How the Banks Brought Ireland to its Knees. Penguin Press, Ireland.

Shiller, R., 2010. The Subprime Solution: How Today's Global Financial Crisis Happened and What to Do About It. Princeton University Press, Princeton, NJ.

Sowell, T., 2010. The Housing Boom and Bust: Revised Edition. Basic Books.

St. Louis Federal Reserve, 2011. Foreign Assets in the US: Net Capital Inflow. Federal Reserve Economic Data. St. Louis Fed. http:// research.stlouisfed.org/fred2/series/BOPI.

Taylor, J., 2008. The Financial Crisis and the Policy Responses: An Empirical Analysis of What Went Wrong. Working Paper. Hoover Institute, Stanford University, CA.

Weston, C., 2009. Damning report on Anglo spells end for financial regulator. Irish Independent January 10th.

Woods, M., 2007. A Financial Stability Analysis of the Irish Commercial Property Market. Financial Stability Report. Central Bank of Ireland. 